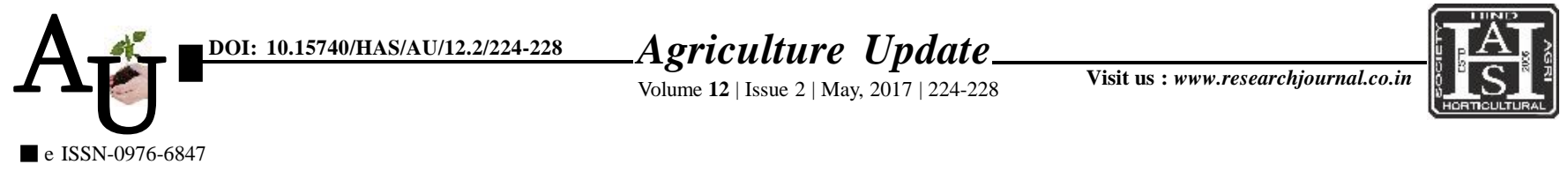

\title{
Research автіcle: Factors associated with the internet utilization behaviour of the students of S.D. Agricultural University
}

MOHMMAD YUNUS AND A.S. SHEIKH

Article Chronicle:

Received :

08.01.2017;

Revised :

10.03.2017;

Accepted :

22.03.2017

KeY Words:

Internet utilization

behaviour, Factor

associate,

Agricultural

university, Students

MOHMMAD YUNUS

B.A. College of

Agriculture, Anand

Agricultural University,

ANAND (GUJARAT) INDIA

Email:mohmmad_yunus@

yahoo.com

See end of the article for

authors' affiliations
SUMMARY : Internet has become a way of life for majority of higher education students all around the world. For most college students, the internet is a functional tool, one that has greatly changed the way they interact with each other and with information as they go about their studies. With internet many students prepare course assignments, make study notes, tutor themselves with specialized multimedia, and process data for research projects. Most students exchange e-mails with faculty, peers, and remote experts. They keep upto- date in fields on the internet, accessing newsgroups, bulletin boards, and websites posted by professional organizations. Most students access library catalogs, bibliographic databases, and academic resource in text, graphics and imagery on the World Wide Web. Internet is an inter-connection between several computers of different types belonging to various networks all over the globe. It is a network of networks. The kind of colossal powers that the internet gives yours machine is mind- bogging. To send or receive data within a matter of seconds to someone placed beyond the pacific was unthinkable before the advent of the internet. The internet represents the transformation and evolution of the entire information age. It is due to these factors that people all over the globe have recognized the internet as their latest developmental tool. "Internet" is one of the tool of communication. Internet has changed life as a few things have done. It has added a new dimension to our existence by placing within easy reach, mind boggling range of information. It gives each of us the option to be as publisher of our information and views, and as the numbers of people on internet multiply and commerce transforms the internet, the opportunities are getting larger.

How to cite this article : Yunus, Mohmmad and Sheikh, A.S. (2017). Factors associated with the internet utilization behaviour of the students of S.D. Agricultural University. Agric. Update, 12(2): 224-228; DOI : 10.15740/HAS/AU/12.2/224-228. 